\title{
Publications received [61]
}

Annual Report of the International Research Institute for Advanced Buddhology for the Academic Year 2005, IX (2006). Tokyo. ISSN 1343-8980. Contents: Oskar von Hinüber, 'Everyday Life in an Ancient Indian Buddhist Monastery', pp. 3-31; Diwakar Acharya \& Noriyuki Kudo, 'The First Three Folio of Manuscript B of the Karmavibhanga', pp. 33-42; Noriyuki Kudo, 'One More Manuscript of the Karmavibhanga in the National Archives of Nepal, Kathmandu: Transliteration of Manuscript E (1)', pp. 43-60; Margarita I. Vorobyova-Desyatovskaya (transl. by Jan Nattier), 'The Central Asian Manuscript Collection of the St. Petersburg Branch of the Institute of Oriental Studies of the Russian Academy of Sciences', pp. 61-78; Seishi Karashima, 'A Trilingual Edition of the Lotus Sutra-New editions of the Sanskrit, Tibetan and Chinese versions (4)', pp. 79-88; Seishi Karashima, 'An Old Tibetan Translation of the Lotus Sutra from Khotan: The Romanized Text Collated with the Kanjur Version (2)', pp. 89-181; Jan Nattier, 'The Names of Amitābha/Amitāyus in Early Chinese Buddhist Translations (1)', pp. 183-199; Chen Ming, 'The Transmission of Indian Ayur-vedic Doctrines in Medieaval (sic) China: A case Study of Astāinga and Tridoșa Fragments from the Silk Road', pp. 201-230; Akira Yuyama, 'Amoghavajra's Uṣṇ̄sa-Vijayā Dhāraṇ̄ from Tunhuang', pp. 231-276 ('Introductory Remarks' in Japanese); Akira Yuyama, 'Miscellanea Philologica Buddhica (IV)', pp. 277-296 (In Japanese); Noriyuki Kudo, 'Brief Communication-A notebook transcribing manuscript B of the Karmavibhanga formerly belonging to the private collection of Hemraj Sharman', pp. 297-300.

Annual of the Sanko Research Institute for the Studies of Buddhism, XXXVII (2006). ISSN 0286-3480. [All 6 articles but one in Japanese.] From the contents: Jin-il Chung, 'Ursprung und Wandel der Aufnahme von Frauen in den buddhistischen Orden nach der kanonischen Überlieferung-eine Rand-bemerkung', pp. 1-16; Jan Nattier, 'The Heart Sūtra: A Chinese Apocryphal Text?', pp. 17-83 [transl. into Japanese by Noriyuki Kudo \& Takamichi Fukita]; Minori Nishimura, 'A point of contact between the Mahāsāmghika and the Aștasāhasrikā', pp. 137-150.

Balbir, Nalini. 'Sur les traces de deux bibliothèques familiales jaina au Gujarat ( $\mathrm{XV}^{e}-$ XVII ${ }^{e}$ siècles).' In: Anamorphoses. Hommage à Jacques Dumarçay. Textes réunis par Henri Chambert-Loire et Bruno Dagens, pp. 325-352. Paris, 2006.

Bechert, Heinz. Eine regionale Hochsprachliche Tradition in Südasien: SanskritLiteratur bei den Buddhistischen Singhalesen. Sitzungsberichte der Österreichi- 
schen Akademie der Wissenschaften, Philos.-hist. Klasse DCCXVIII, Veröffentlichungen zu den Sprachen und Kulturen Südasiens XXXVII. Verlag der Österreichischen Akademie der Wissenschaften, Wien, 2005. ISBN 3-7001-3361-8, pp. 173.

Berger, Peter. Füttern. Speisen und Verschlingen. Ritual und Gesellschaft im Hochland von Orissa. Indien. INDUS Ethnologische Südasien-Studien Band 11. Lit Verlag, Berlin, 2007.

Chung-Hwa Buddhist Journal, X (2006). Taipei. ISSN 1026-969X. From the contents $[9$ articles in Chinese with English summaries \& 2 articles in English with Chinese summaries]: Yen Wei-Hung, 'Prajñapti in the Prajñāpāramitā Sūtras: A Comparison between the "Sarvākārajñāta-caryā Parivarta" in the Așta and the "Subhūti Parivarta" in the Pañca', pp. 43-70; Tang Xiulian, 'The Buddhism of Kucha and Central Asia: From the Han to the Period of Kumārajīva', pp. 71-106; Yang Fuxue, 'A Study of a Uighur Version of the Buddha's Biography: Turpan Manuscript Mains 131 (T II Y 37)', pp. 239-253; K. T. S. Sarao, 'On the Question of Animosity of the Brāhmaṇas and Persecution by Brāhmaṇical Kings Leading to the Decline of Buddhism in India', pp. 255-293; Märt Läänemets, 'Bodhisattva Avalokitesvara in the Gạ̣davyūhasūtra', pp. 295-339.

Chung-Hwa Buddhist Journal [Commemorative Volume in Honor of Professor Yang Yuwen's Seventieth Birthday], XIX (2006). Taipei. ISSN 1017-7132. From the contents [All but one in Chinese, with English summaries]: Aming Tu, Ray Chou \& Shi Fa-Yuan, 'Āgama Research in the Information Age: The Digitization of the Agama Dictionary', pp. 73-105; Tsai Chi-lin, 'Discussion of the Present Situation and Future Prospects of Pāli Digital Resources: With Some Remarks on the Multilingual Parallel Corpus of Early Buddhist Texts', pp. 107-146; Yueh Jiandong (Kin-Tung Yit), 'Stereotyped Structure of the Path in Early Buddhist Literature: A Comparative Study of the Four Pāli Nikāyas and the Four Chinese Āgamas', pp. 147-178.

Clarke, Shayne. 'Miscellaneous Musings on Mūlasarvāstivāda Monks. The Mūlasarvāstivāda Revival in Tokugawa Japan.' Japanese Journal of Religious Studies, XXXIII (2006): 1-49.

Deleanu, Florin. The Chapter on the Mundane Path (Laukikamārga) in the Śrāvakabhūmi: A trilingual Edition (Sanskrit, Tibetan, Chinese), Annotated Translation, and Introductory Study, Studia Philologica Buddhica: Monograph Series XX. International Institute for Buddhist Studies, Tokyo, 2006. ISBN Volume One: 4-906267-54-8 \& ISBN Volume Two: 4-906267-55-6.

Doyama, Eijiro. 'A morphological study of the first person subjunctive in the Rigveda.' Machikaneyama Ronsō, XXXIX (2005): 1-19.

Eimer, Helmut. 'Zum tibetischen Dkar Chag des Yongle-Kanjur.' Asiatische Studien: Zeitschrift der Schweizerischen Asiengesellschaft / Études Asiatiques: Revue de la Société Suisse-Asie, LX (2006)(2): 307-320.

Franke, Herbert (ed.). Wörterbuch der tibetischen Schriftsprache: 1. ka-kun chub par byed-pa. Im Auftrag der Kommission für zentral- und ostasiatische Studien der Bayerischen Akademie der Wissenschaften. Verlag der Bayerischen Akademie der Wissenschaften, in Kommission beim Verlag C. H. Beck, München, 2005. ISBN 3-7696-0934-4, pp. 1xiii, 64. Bearbeitet von Helga Uebach. 
Fujimoto, Akira. 'Is the Law of Kammassakatā Violated in the Context of "Offer of Donation".' Buddhist Studies [Bukkyō Kenkyū], XXXIII (2005): 1-31.

'How to Enter the First Jhäna.' Journal of Indian and Buddhist Studies [IBK], LIV (2006)(3): 1171(59)-1175(63).

. A Study of Merit Transference-With Reference to Pali Peta Stories, Ratna Buddhist Series I. International Buddhist Association, Hamamatsu, 2006. ISBN 4-9903148-0-8, pp. xxiii, 372. With forewords by Shōryū Katsura \& Sodō Mori [In Japanese with English summary].

Fujimoto, Yumi. 'On the Meaning of Pāli junha.' Ronshū: Studies in Religions East and West, XXIX (2002): 65-84. [In Japanese].

'Nissaggiya 28 and Giving Robes after the Rain-Retreat.' Journal of Indian and Buddhist Studies [IBK], LIV (2006)(2): 993(120)-989(124). [In Japanese].

German Indology. A list of institutions and persons concerned with Sanskrit and associated studies, (2007). Leipzig. Compiled by Dieter Schlingloff.

Harikai, Kunio. 'Sanskrit text of the Tantravārttika Adhyāya 1, Pāda 4. Collated with four Manuscripts.' Annual Report of Medical Anthropology and Humanity, (2006)(1): 1-57.

von Hinüber, Oskar. 'Les documents épigraphiques indiens: Difficultés de leur interprétation-Examples concernant l'irrigation.' In: Académie des Inscriptions et Belles-Lettres. Comptes Rendus des Séances de l'Année 2004. Avril-Juin. Paris 2004, pp. 989-1011. 2006.

Hokke Bunka Kenkyū (Journal of the Institute for the Comprehensive Study of Lotus Sütra), XXXI (2005). ISSN 0287-1513. Contents [In Japanese with English summaries]: H. Yasuda, 'Early Gandhāran Images of the Buddha on a Lotus Petal Throne - the Development of the Ideal Buddha in Mahāyāna Thought', pp. 1-23; Z. Itoh, 'A consideration of Eka-yāna and Tri-yāna theories viewed from a perspective of comparative exegesis of the sutras, 2: An analysis of Eka-yāna and Tri-yāna theories in Saddharmapundarīka-sūtra', pp. 25-35; K. Mitomo, 'The Studies and Decipherment of Chapter V of the Abhidharmadipa (2)', pp. 36-68; J. Chou, 'An Investigation into the Theory of Trinni Kuśalamūlāni Relating to the Nirvedha-Bhägiya: A Review of the Preface to the Ananta-Nirdeśa', pp. 69-84.

Indologica Taurinensia: Official Organ of the International Association of Sanskrit Studies. Proceedings of the XI ${ }^{\text {th }}$ World Sanskrit Conference (Turin, April 3-8, 2000) Part I, XXIX (2003). Edizioni A. I. T., Torino. ISSN 1023-3881. Contents: [A: Proceedings of the XI ${ }^{\text {th }}$ World Sanskrit Conference]-Greg Bailey, 'The pravrtti/nivrtti project at La Trobe University. With notes on the meaning of $v r t$ in the Bhagavadgita', pp. 11-30; Piotr Barcerowicz, 'On the relationship of the Nyāyāvatāra and the Sammati-tarka-prakarana', pp. 31-83; Alberto Chiantaretto, 'Nā dīparīkāā as diagnostic and prognostic technique in Sanskrit medical literature and the Nāḍijñāna of Kanāda', pp. 85-102; Bruno Dagens, 'Temple architecture in India at the beginning of the $6^{\text {th }}$ century according to Varāhamihira's Bṛhatsamhitā', pp. 103-122; Jean Michel Delire, 'The Baudhāyana Śulbasūtra's commentaries: edition, translation and explanations', pp. 123-143; M. G. Dhadphale, 'Sūkaramaddava: a new interpretation', pp. 145-149; John R. Dypuche, 'Abhinavagupta's presentation of the Kula Ritual in Tantrāloka 29', pp. 151-162; Carlos Alberto da Fonseca, 'Theoretical base for Yāska's Nirukta', pp. 163-170; A. W. P. Guruge, 'Allusions to the Rāmāyaña in Buddhist Sanskrit Literature', 
pp. 171-187; Marta Kudelska, 'The problem of immortality and the notion of the term nāman', pp. 189-196; D. N. Lielukhine, " "Administrative" terminology in early epigraphy and evolution of ancient Indian state structure (I-V sec. a. d)', pp. 197-203; M. I. Mikhailov, 'Vedic night Prthivi and the date of the Rgveda', pp. 205-227; Gopinath Mohapatra, 'A most popular translation of Bhāgavata Purāna in the mediaeval Orissa', pp. 229-239; Juan Miguel de Mora, 'Was Bhavabhūti irreverent in the Uttararāmacarita', pp. 241-246; Roberto Perinu, 'Shape \& tuning of some wind musical instruments', pp. 247-267; Daniela Rossella, 'The Bhānudatta's Rasamañjarī. The first translation in western language', pp. 269-293; Prīti Sinhā, 'Sanskrit Stotra-tradition, with special reference to the Stotra's of Rāmabhadra Dīkșita', pp. 295-315; Fernando Tola \& Carmen Dragonetti, 'The Lotus Sūtra as an apologetic work', pp. 317-326. [B: Proceedings of the XII ${ }^{\text {th }}$ World Sanskrit Conference (Helsinki, July 14-19, 2003)]-John L. Brockington, 'Report on the twelfth World Sanskrit Conference', pp. 329-330; 'Meetings of the I. A. S. S. during the $12^{\text {th }}$ World Sanskrit Conference held in Helsinki', pp. 331-334; etc.

Indologica Taurinensia: Official Organ of the International Association of Sanskrit Studies. Proceedings of the XI ${ }^{\text {th }}$ World Sanskrit Conference (Turin. April 3-8, 2000) Part II, XXX (2004). Edizioni A. I. T., Torino. ISSN 1023-3881. Contents: O. P. Bharadwaj, 'The Rgvedic River Rasā', pp. 9-26; Anasuya Bhowmik, 'Vāstumaṇana - a treatise on architecture of $15^{\text {th }}$ century A. D.', pp. 27-34; Didhiti Biswas (Chakrabarti), 'Synonyms in Nighaṇtu (a semantic approach after Yāska)', pp. 35-49; Mikhail D. Bukharin, 'Early royal dynasties in the purānas, epics and classical tradition', pp. 51-80; Samir Kumar Dattaj, 'The concept of aucitya. Acceptability and applicability in modern sanskrit', pp. 81-87; Jonardon Ganeri, 'The practice of Reason in ancient India', pp. 89-97; Rama Ghose, 'The philosophy of Vīraśaivism, with special reference to Anubhavasūtra, pp. 99-110; Manijukika Ghosh, 'Dharmaśāstra versus Arthaśāstra', pp. 111-119; Klara Gönc Močanin, 'Nātyamaṇdapa-a real or fictional performing space of the classical Indian theatre', pp. 121-131; Jörg Grafe, 'Vidyādhara's in Indian lexicography', pp. 133-138; Kamla Jain, 'Relevance of Jaina Economic Philosophy in Modern Times', pp. 139-146; Marja ydwika Jarocka, 'Water in the $R g$ Veda', pp. 147-160; Toshihiko Kimura, 'Vita and A-/āvita dialectics of the Sāmkhyas', pp. 161-167; Katharina Kupfer, 'Possible slots in the opening of a pāda', pp. 169-176; Mirella Lingorska, 'Theoretical similes in Ānandavardhana's Dhvanyāloka', pp. 177-184; Asko Parpola, 'Bala-Rāma and Sìtā: on the origins of the Rāmāyaṇa', pp. 185-200; Primoz Pecenko, 'The È̄kās in the Four Nikāyas: Lìnatthapakāsin̄̄ and Sārathamañjūsā', pp. 201-227; Ferenc Ruzsa, 'The Meaning of Āruni's Promise', pp. 229-235; San Sarin, 'Mahābhärata: the numbers 18 and 108 through akșauhin̄̄', pp. 237-252; Adheesh Sathaye, " "Higher" Learning: a Comparative Study of Counter-Normative Guru-Śisya Narratives in the Upaniṣads and the Mahābhārata', pp. 253-264; Hari Dutt Sharma, 'Inter-relation between sentiment, embellishment and metrical arrangement in Sanskrit poetry', pp. 265-278; Ram Karan Sharma, 'Pratyayas in Indian Metrics', pp. 279-290; A. R. Tripathi, 'The concept of Shudras in Manu Smriti: a reappraisal', pp. 291-301; Koshalya Walli, 'Relevance of Abhinavagupta in modern era', pp. 303-311. 
Indologica Taurinensia: Official Organ of the International Association of Sanskrit Studies, XXXI (2005). Edizioni A. I. T., Torino. ISSN 1023-3881. Content: W. B. Bollee, 'Tales and Similes from Makayagiri's commentary on the Vyavahārabhāṣya (bhāga 29)', pp. 9-90; Christian Bouy, 'Quelques remarques sur 1'Āgamaśāstra de Gauḍapāda', pp. 91-102; J. Duncan M. Derrett, 'Athanasius, Anthony, and the Buddha', pp. 103-120; T. Y. Elizarenkova, 'The word ätman in the Rgveda', pp. 121-134; Ananda W. P. Guruge, 'Who were Upagupta and his Aśoka?', pp. 135-158; Advaitavadini Kaul, 'Buddhism in Kashmir', pp. 159-172; B. B. Lal, 'Can the vedic people be identified archaeologically? An Approach', pp. 173-194; Stephan Hillyer Blevitt, 'Why are Sanskrit Play Titles Strange?', pp. 195-232; D. Saklani, 'Questioning the "Questioning of Ramayanas" in historical context', pp. 233-262; Hartmut Scharfe, 'Pāṇini and his Predecessors', pp. 249-262; Fabio Scilpi, 'Professor Giuseppe Tuci', pp. 263-272; Ram Karan Sharma, 'Long Live K. V. Sarma (obituary)', pp. 273-276; Toshihiro Wada, 'Vāsudeva on the Vyāptipañcaka Section of Gangeśa's Tattvacintāmaṇi (1)', pp. 277-300; 7 reviews on pp. 303-310.

International College for Postgraduate Buddhist Studies Library. List of Publications Received (Publications received from April 2004 to March 2005), VIII. International College for Postgraduate Buddhist Studies Library, Tokyo, 2006, pp. 40.

Journal of South Asian Languages and Cultures, IV (2006). South and West Asian Studies, Faculty of Foreign Languages, Tokyo University of Foreign Studies, Tokyo. Contents [In Japanese]: Teiji Sakata, 'Toward Editing and Publishing a History of South Asian Literature', pp. 1-9; Yoshifumi Mizuno, 'Is the kāvyaśāstra mere poetics?-Focusing on a color symbolism in Indian Literature', pp. 10-21; Masayuki Usuda, 'On the Relation of History and Literature in the Historical Description of Indian Literature', pp. 22-28; Nobuhiro Ota, 'A survey of courtly literature in Karnataka: languages of literary writings and their historical changes', pp. 29-57; So Yamane, 'A Study on Urdu Materials of the Late Mughal Period', pp. 58-79; Takamitsu Matsumura, 'Some Comments on Prof. So Yamane's Paper "A Study on Urdu Materials of the Late Mughal Period" ', pp. 80-84; Tamaki Matsuoka, 'The Traces of Indian Cinema in Japan', pp. 85-117.

Journal of the International College for Postgraduate Buddhist Studies, X (2006). Tokyo. ISSN 1343-4128. Contents [partly in Japanese]: Junkichi Imanishi, 'The Four Noble Truths and Buddha', pp. 1-40; Toshinori Ochial, 'The Translation of the Abhidharmamahāvibhāsāśs̄astra and the Compilation of Its Compendium: An Attempt to Restore the Wenyi cidi', pp. 41-84; Silvie Hureau, 'Preaching and Translation on poṣadha days: Kumārajīva's Role in Adapting an Indian Ceremony to China', pp. 86-118; Hurbert Durt, 'The Shijapu of Sengyou: The First Chinese Attempt to Produce a Critical Biography of the Buddha', pp. 119-154; Kiyotaka Kimura, 'Buddhism and the Concept of he ( $w a$ in Japanese) in East Asia', pp. 155-175; Minoru Kara, 'A Note on the Brahmājjhesana', pp. 172-204.

Journal of the Pali Text Society, XXVIII (2006). Lancaster. ISBN 0-86013-419-9. Contents: K. R. Norman, 'The Anāgatavamsa Revisited', pp. 1-37; Jinadasa Lyanaratne, 'Sri Lankan Manuscriptology', pp. 39-48; Kate Crosby, 'Sāriputta's Three Works on the Samantapāsādikā', pp. 49-59; Peter Jackson, 'The Canonicity of the Netti and Other Works', pp. 61f; Rupert Gethin, 'Mythology as Meditation: From the Mahāsudanassa Sutta to the Sukhāvativyūha Sūtra', pp. 63-112; 
Peter Skilling, 'Jātaka and Paññāsa-jātaka in South-East Asia', pp. 113-173; List of 10 'I. B. Horner Lectures', p. 175; 'An Index to JPTS Volumes IX-XXVIII', pp. 177-183.

Karashima, Seishi. 'An Old Tibetan Translation of the Lotus Sutra from Khotan: The Romanized Text Collated with the Kanjur Version (2).' Annual Report of The International Research Institute for Advanced Buddhology, IX (2006): 89-181.

'Underlying Language of Early Chinese Translations of Buddhist Scriptures.' In: Anderl, Christoph \& Halvor Eifring (eds.), Studies in Chinese Language and Culture: Festschrift in Honour of Christoph Harbsmeier on the Occasion of his $60^{\text {th }}$ Birthday, pp. 355-366. Hermes Academic Publishing, Oslo, 2006.

Karashima, Seishi \& Klaus Wille (eds.). Buddhist Manuscripts from Central Asia: The British Library Sanskrit Fragments. Volume I. IRIAB, Tokyo, 2006. ISBN 4-9980622-9-8, pp. v, 274. Contents: Ursula Sims-Williams, 'The papers of the Central Asian Scholar and Sanskritist Rudolf Hoernle', pp. 1-26; Klaus Wille, 'Some recently identified Sanskrit fragments from the Stein and Hoernle collections in the British Library (2)', pp. 27-64; K. Wille, 'The Sanskrit fragments Or. 15003 in the Hoernle Collection', pp. 65-153; Seishi Karashima, 'The Saddharmapundarīkasūtra Manuscript from Farhād-Bēg in the Stein Collection (1)', pp. 155-172; S. Karashima, 'A Sanskrit Fragment of the Saddharmapundarīkasūtra in the Stein Collection', pp. 173-175; S. Karashima, 'Four Sanskrit Fragments of the Ratnaketuparivarta in the Stein Collection', pp. 177-189; S. Karashima \& K. Wille, 'The Sanskrit Manuscript of the Sarvabuddhavișayāvatārajñānālokālamkāra from Enderei in the Stein Collection', pp. 191-254; Noriyuki Kudo, 'A Sanskrit Fragment of the Larger Prajñāpāramitā in the Stein Collection', pp. 255-259; Kenta Suzuki, 'A Sanskrit Fragment of the Prajñāpāramitāstotra in the Stein Collection', pp. 261f; N. Kudo, 'A Sanskrit Fragment of the Caityacatuska- and Tripusabhallikasūtra', pp. 263f; N. Kudo, 'A Sanskrit Fragment of Unknown Mahāyāna Charm', p. 265; Tatsushi Tamai, 'The Tocharian Fragments in Or. 15003 of the Hoernle Collection', pp. 267-269.

Katz, Joshua T. 'Sanskrit sphij/sphigī and Greek 'phikis'.' In: Hyllested, Adam, Anders Richardt Jørgensen, Jenny Helen Larsson, \& Thomas Oleander (eds.), Per aspera ad asteriscos. Studia Indogermanica in honorem Jens Elmegàrd Rasmussen sexagenarii Idibus Martiis anno MMIV, Innsbrucker Beiträge zur Sprachwissenschaft Band 112, pp. 277-284. Innsbruck, 2004.

Kellens, Jean. 'En amont du moyen-iranien: La lexicographie avestique.' In: Cereti, Carlo G. \& Mauro Maggi (eds.), Middle Iranian lexicography. Proceedings of the Conference held in Rome, 9-11 April 2001, Serie Orientale Roma, pp. 41-47. Istituto Italiano per 1'Africa e 1'Oriente, Roma, 2005.

. 'Langues et religions indo-iraniennes.' In: Cours et Travaux du Collège de France. Résumés 2004-2005, pp. 641-650. Paris, 2006.

Kimura, Takayasu (ed.). Pañcavimsśatisāhasrikā Prajñāpāramitā VI-VIII. Sankibo Busshorin Publishing, Tokyo, 2006. ISBN 4-7963-1024-X, pp. 189.

Lienhard, Siegfried. '[Review of] Klaus Mylius, Geschichte der altindischen Literatur [Wiesbaden 2003].' Acta Orientalia, LXV (2004): 179-183.

. '[Review of] Leo Both, Hemacandras Kāvyānuśāsana Kapitel 1 und 2. Eine Einführung in die Grundlagen des indischen Dramas und der indischen Poesie [Wiesbaden 2002].' Acta Orientalia, LXV (2004): 176-179. 
Mayrhofer, Manfred. Einiges zu den Skythen, ihrer Sprache, ihrem Nachleben. Österreichische Akademie der Wissenschaften. Philosophisch-Historische Klasse. Sitzungsberichte, 742. Band. Verlag der Österreichischen Akademie der Wissenschaften, Wien, 2006, pp. 48.

Michaels, Axel. The Price of Purity. The Religious Judge in $19^{\text {th }}$ Century Nepal Containing the Edition and Translation of the Chapters on the Dharmādhikārin in Two (Mulukī) Ains, Corpus Iuris Sanscriticum et Fontes Iuris Asiae Meridiane et Centralis VI. Torino, 2005, pp. 164.

Pinault, Georges-Jean. 'L'indo-iranien et les nouvelles langues apparues en Asie Centrale dans le travail d'Antoine Meillet.' In: Bergounioux, Gabriel \& Charles de Lambertine (eds.), Meillet Aujourd'hui, Collection Linguistique publié par la Société de Linguistique de Paris LXXXIX, pp. 191-243. Leuven-Paris, 2006.

Schopen, Gregory. 'On monks and menial labourers. Some monastic accounts of building Buddhist monasteries.' In: Callieri, Pierfrancesco (ed.), Architetti, capomastri, artigiani: L'organizzazione dei cantieri e della produzione artistica nell'Asia ellenistica. Studi offerti a Domenico Faccenna nel suo ottantesimo compleanno, Serie Orientale Roma C, pp. 225-245. Istituto Italiano per l'Africa e l'Oriente, Roma, 2006.

'A Well-Sanitized Shroud. Asceticism and Institutional Values in the Middle Period of Buddhist Monasticism.' In: Olivelle, Patrick (ed.), Between the Empires. Society in India 300 BCE to 400 CE, pp. 315-347. Oxford University Press, Oxford, 2006.

Seyfort-Ruegg, David. 'Introductory Remarks on the Spiritual and Temporal Orders.' The Relationship between Religion and State (chos srid zung 'brel) in Traditional Tibet. Proceedings of a Seminar Held in Lumbini, Nepal, March 2000 (2004): 9-13.

Shōno, Masanori. 'Towards a re-edition of the Varsāuvastu.' Machikaneyama Ronsō (2005): 21-39.

. 'On adhikarana.' Journal of Indian and Buddhist Studies, LIV (2006)(3): $55-58$.

Skilling, Peter \& Paul Harrison. 'What's in a Name? Sarvāstivādin Interpretations of the Epithets "Buddha" and "Bhagavat". In: Hojun Nagasaki Volume, pp. 700(131)-675(156). Kyoto, 2005.

Sugimoto, Takushū. 'Jātakas Depicted in Ajantā Caves (2).' In: Buddhism and Jainism, Essays in Honour of Dr. Hojun Nagasaki on His Seventieth Birthday, pp. 381-407. Heirakuji Shoten, Kyoto, 2005. [In Japanese].

. 'Jātakas Depicted in Ajantā Caves (4).' Proceedings of Kinjō University, VI (2006): 73-97. [In Japanese].

. 'The Transition of the Jātakas, Taking the Chaddanta-/Saddanta- $J^{\circ}$ as an Example.' Hokuriku Religious Culture, XVIII (2006): 1-33. [In Japanese].

Sumanasara, Alubomulle \& Akira Fujimoto. Practical Psychology of the Buddha: Analysis of Mind. Abhidhamma Discourse II. Samgha, Tokyo, 2006. ISBN 4-901679-16-3, pp. 379. [In Japanese].

Taisho University: Study Group on Buddhist Sanskrit Literature, Institute for Comprehensive Studies of Buddhism. Vimalakītinirdeśa: A Sanskrit Edition Based upon the Manuscript Newly Found at the Potala Palace. Taisho University Press, Tokyo, 2006. ISBN 4-924297-34-8, pp. xxvii, 128. 
Today and Shinran, X (2006). ISSN 1347-4316. From the contents [all papers in Japanese]: Takateru Hazuka, 'A Note on the Concept of Sarvajña in Buddha's Biography Literature and the Milindapañha', pp. 2-27.

Tola, Fernando \& Carmen Dragonetti. 'Unity in Diversity: Indian and Western Philosophical Traditions.' In: Squarcini, Federico (ed.), Boundaries. Dynamics and Construction of Tradition in South Asia, pp. 607-618. Munshiram Manoharlal/Firenze University Press, New Delhi, 2005.

Tremblay, Xavier. 'Bildeten die iranischen Sprachen ursprünglich eine genetische Familie oder einen Sprachbund innerhalb des indo-iranischen Zweiges?' In: Meiser, Gerhard \& Olaf Hackstein (eds.), Sprachkontakt und Sprachwandel. Akten der XI. Fachtagung der Indogermanischen Gesellschaft, 17.-23. September 2000, Halle and der Saale, pp. 673-688. Dr. Ludwig Reichert Verlag, Wiesbaden, 2005.

. 'Indo-Tocharica et Tocharo-Iranica.' BSOAS, LXVIII (2005): 421-449.

'Iranian Historical Linguistics in the Twentieth Century.' Indo-European Studies Bulletin. University of California at Los Angeles, XI (2005)(1): 1-23.

Werba, Chlodwig H. 'mavrēe-rā na bāyad ziyād kard be joz-e ehtiyāj. (Indo-)Iranische Rekonstrukte als textkritisches Korrektiv in der Altiranistik.' In: Cereti, Carlo G. \& Mauro Maggi (eds.), Middle Iranian lexicography. Proceedings of the Conference held in Rome, 9-11 April 2001, Serie Orientale Roma XCVIII, pp. 261-306. Istituto Italiano per l'Africa e l'Oriente, Roma, 2005.

Yonezawa, Yoshiyasu. 'Lakṣanatīkā Sanskrit Notes on the Prasannapadā (3).' Journal of Naritasan Institute for Buddhist Studies, XXIX (2006): 135-163.

Zimmermann, Michael (ed.). Buddhism and Violence. LIRI Seminar Proceedings Series II. Lumbini International Research Institute, Lumbini, 2006. ISBN 99946933-1-X, pp. 254. Contents: Michael Zimmermann, 'Introduction', pp. 5-10; Francis Brassard, 'The Path of the Bodhisattva and the Creation of Oppressive Cultures', pp. 11-23; Martin Delhey, 'Views on Suicide in Buddhism: Some remarks', pp. 25-63; Christoph Kleine, 'Evil Monks with Good Intentions? Remarks on Buddhist Monastic Violence and its Doctrinal Background', pp. 65-98; Carmen Meinert, 'Between the Profane and the Sacred? On the Context of the Rite of "Liberation" (sgrol ba)', pp. 99-130; Jens Schlieter, 'Compassionate Killing or Conflict Resolution? The Murder of King Langdarma according to Tibetan Buddhist Sources', pp. 131-157; Brian Victoria, 'D. T. Suzuki and Japanese Militarism: Supporter or Opponent', pp. 159-194; Buddhism and the Killing of Animals in Premodern Japan', pp. 195-211; Michael Zimmermann, 'Only a Fool Becomes a King: Buddhist Stances on Punishment', pp. 213-242. 